\title{
Evaluation of Extension Agents' Communication Strategies in Promoting the New Rice for Africa Technology Among Rice Farmers in Ofada, Ogun State, Nigeria
}

\author{
Helen Odunola Adekoya Charles Maduabuchi Ekeh \\ Department of Mass Communication, Babcock University, Ilishan-Remo, Ogun State Nigeria
}

\begin{abstract}
This study focused on evaluating the effectiveness of extension agents' communication strategies in promoting the New Rice for Africa Technology among farmers in Ofada, Ogun State, Nigeria. Hinged on the Diffusion of Innovations Theory, the study adopted the survey research design using structured questionnaire and focused group discussion sessions to elicit data from extension workers and rice farmers respectively. Findings from the study revealed that extension agents employed communication strategies such as one-to-one, group gatherings, radio jingles, short sms, and video demonstrations among others to promote NERICA among rice farmers in Ofada. It was also gathered that these communication strategies were effective in passing across required information however; the farmers prefer the one-to-one than the group gathering communication strategy which was more often used by the extension workers. This preference was premised on the inherent advantage of interactivity which the adoption of the one-to-one technique could provide. In the light of these findings, it was recommended that, more needed to be done by the extension agents and the government to ensure adoption of NERICA technology. With the right seedlings, good preservation techniques, and other backup supports such as availability of pesticides, herbicides and fertilizers, adopting NERICA technology would be easier for farmers. The study recommended use of the one-to-one communication strategy and periodic evaluation of the extension worker's activities by government.
\end{abstract}

Keywords: Communication; Communication Strategies; Agricultural Extension Agents, NERICA, Rice Farmers DOI: 10.7176/DCS/9-6-06

Publication date:June $30^{\text {th }} 2019$

\section{Introduction}

The role of agriculture in economic development and growth of a nation cannot be overemphasized. Agriculture can play a unique role in achieving food security and serve as an important engine for economic growth especially in developing countries. This is due to the large number of people engaged in it and its capability to foster food production and generation of substantial income, thereby reducing poverty and starvation. That an estimated 70 percent of the labor force in sub-Saharan Africa work in the agricultural sector is a pointer to the fact that agriculture can serve as a springboard to national development by contributing substantially to the Gross Domestic Product (GDP) of any nation (Ali, Mohammad, \& Ebraheem, 2012).

Although the economy of Nigeria is highly dependent on crude oil, the country has recognized the need to invest heavily in promoting agriculture. Since early post-independence, Nigeria has witnessed diverse agricultural intervention programmes by 'successive governments designed specifically to improve productivity in the agricultural sector. These initiatives emerged out of government's concern that the agricultural sector must develop the capacity to provide the nation's food, industrial raw materials and generate foreign exchange. Programmes such as Operation Feed the Nation (OFN), Green Revolution (GR), the Directorate of Food, Road and Rural Infrastructure (DFRRI), the River Basin and Rural Development Authorities, the World Bank assisted Agricultural Development Programme (ADP) and most recently Anchor Borrowers Programme for farmers were all attempts by government at various times aimed at improving the capacity of the agricultural sector (Chukwuemeka \& Nzewi, 2011). Despite all these seemingly laudable initiatives and agricultural development programmes by successive governments, Nigeria, known as the most populous black nation in the world, with a population of over 180 million people, is still faced with food insecurity. Rice is perhaps the world's most important food crop, being the staple food of over $50 \%$ of the world population, particularly in India, China, and a number of other countries in Africa and Asia (Ogundele \& Okoruwa, 2006). In Africa, particularly in the 1980s, Egypt and Malagasy Republic account for 62\% of all rice produced (Akpokodje, Lancon \& Olaf, 2002). One of the major agricultural products grown in Nigeria is rice. Although rice is primarily a cash crop in Nigeria, it also serves as a common staple food for many people across the country. In rice producing areas, the enterprise also provides employment for more than 80 per cent of the inhabitants in various activities along the production/distribution chain from cultivation to consumption.

The Nigerian rice sector attracts special attention within the West African sub-region because of the population of the country as well as its vast land area where rice could be cultivated. Nigeria has a potential 5 million hectares of land that spread across all the ecological zones, suitable for rice cultivation (Ojehomon, 
Ayinde, Adewumi, \& Omotesho 2013). Yet, Nigeria still imports rice. The major reason for the importation is the inability of the local farmers to meet domestic demand due to low productivity. In Nigeria, the average yield of upland and lowland rain-fed rice is 1.8 ton per hactare, while that of the irrigation system is 3.0 ton/ha (PCU, 2002). This is very low when compared with 3.0 ton/ha from upland and lowland systems and 7.0 ton/ha from irrigation systems in places like Côte d'Ivoire and Senegal (WARDA and NISER, 2001). It therefore appears that rice farmers in Nigeria are not getting maximum return from the resources committed to the enterprise.

Some remarkable developments however have taken place in the rice production sector particularly in the last twenty years, both in terms of quality and the quantity of rice being produced. For example, before this period, the famous locally produced rice in Abakaliki, Ebonyi state popularly known as "Abakaliki rice" was known for containing large amount of stones due to the crude processing methods employed by rice farmers at that time. Presently, rice processing methods have significantly improved not just in Ebonyi state, but across the country to the extent that some locally produce rice can stand side by side with some imported ones. Also, both production and consumption have increased during this period, although the increased production is not sufficient to match the consumption increase, with rice imports making up the shortfall. The Food and Agriculture Organization (FAO) noted in 2001 that the demand for rice in Nigeria has been increasing at a much faster rate than in any other African country since the mid-1970s (FAO, 2001). Ogundele and Okoruwa (2006) also observed that during the 1960s, Nigeria had the lowest per capita annual consumption of rice in the subregion at an annual average of $3 \mathrm{~kg}$. Whereas, since then, Nigeria's per capita consumption levels have grown significantly at $7.3 \%$ per annum. A worrisome issue about this trend as noted earlier is that local productions have not been able to match the increase in local consumption of rice. Per capita consumption ratio has risen from $3.0 \%$ to $22 \%$ but the country's self-reliance ratio in rice production has dropped from $99 \%$ in the sixties to $79 \%$ between 1995 and 2000, with importation of the commodity rising to fill the lacuna created by low local production rate.

The need for improvement of rice production across Sub-Sahara Africa led the West Africa Rice Development Agency (WARDA) to discover a new technology for rice farming specifically targeted at boosting rice production in African countries in 1991 (Tiamiyu, 2008). Through a special hybridization breeding programme, the New Rice for Africa (NERICA) technology was born. WARDA has since then disseminated this technology across many African countries including Nigeria. Surprisingly, most African countries where NERICA technology was successfully implemented have witnessed significant improvement in local rice production except Nigeria (Tiamiyu, 2008). Could this be linked to poor information dissemination strategies or perhaps faulty communication strategies employed by extension workers who are saddled with the responsibility of passing down the knowledge about NERICA to farmers?

A major challenge militating against the production of rice in sufficient quantity as it does to the production of many other farm products in Nigeria is technical inefficiency. Tchale (2009) has argued that due to lack of technical capacity, smallholder farmers experience low yields, which would almost double "if technical efficiency in smallholder farming systems could be increased by up to $40 \%$ on average, using the current production technology". This means that the potential exists for not just rice farmers but other farmers as well to double or even triple productivity. However, for this to happen, access to technological innovations, in terms of farming equipment, inputs, such as improved seed, availability and use of chemical fertilizers, information on proper spacing, insect and pest control, and prevention of post-harvest losses is crucial.

Given the high illiteracy rate among farmers and their little means of livelihood, the need for agricultural extension services becomes highly imperative. Agricultural extension and communication are critical in helping these farmers gain access to resources and improve their knowledge in food production. Effective communication system requires the synergistic interdependence of the elements in the communication process (Ogidi, 2015). Communication strategies represent the overall approach adopted in information dissemination. It encompasses communication methods, which are means through which information or messages are transmitted to an audience or receiver (Ogunremi, 2013). Access to information through improved communication strategy is a crucial requirement for sustainable agricultural development (Agunga \& Manda, 2014). The emergence of modern sophisticated machines and other technological advancement in the agricultural sector have made it imperative that existing technologies and new ones be disseminated to the farming audience on a regular basis.

Agricultural extension is basically aimed at providing farmers with essential knowledge and skills that would assist them in taking vital decisions which would ultimately lead to increased production (Ephraim \& Gloria, 2013). Extension agents therefore, will need to carefully adapt communication strategies and channels to effectively pass on the required message in each local situation. Effective communication between change agents and researchers is essential for increasing agricultural production through the use of improved technologies. Communication involves exchange of ideas between two or more individuals in an attempt to arrive at a convergence in meaning. Agricultural extension by its nature has an important role in promoting the adoption of new technologies and innovations in agriculture (Jamilah, Azril, Jegak, Asiah \& Azman (2010). Extension workers go to meet with farmers in their homes, farms, markets or during town hall meetings and make them 
aware of the latest farming technologies and techniques. They also encourage them to adopt these techniques so as to enhance crop productivity level and possibly upgrade from small scale farmers to large scale farmers. Agricultural extension brings about changes through education and communication in farmers attitude, knowledge and skills. The role of agricultural extension includes dissemination of information; building capacity for farmers through the use of a variety of communication strategies and helping farmers make informed decisions (Sinkaiye, 2005). If extension agents fail to communicate the desired information the undesired information may circulate among farmers thereby leading to possible undesired results.

The success or failure of a communication programme depends on the encoding-decoding process. Blumberg (1987) pointed out that formal, official structure of an organization defines status that are related to each other and between which communications are expected to take place. He further stated that communication lines consist of downward, horizontal or lateral patterns that can be both formal and informal. The purpose of communication in this regard is to facilitate the achievement of extension goals. The operational procedures for achieving organizational goals involve utilization of functional communication strategies. Extension education is the primary process through which farmers can learn the reasons for change, the value of change and the results that can be achieved through change (Ogunremi, 2013). Extension education is a type of education that is functional rather than formal and its main task is to convey meaningful information to the farmers. It is the major source through which farmers are made aware of alternative farming methods from where they can choose the most desirable for carrying out their farming operations (William, Fenley \& Williams, 1984).

This study was premised on the Diffusion of Innovations Theory. The theory seeks to explain how, why, and at what rate new ideas and technology spread. Developed by Everett Rogers, (1962), the theory argues that diffusion is the process through which an innovation is communicated over time among participants in a social system, and proposes that four main elements influence the spread of a new idea: the innovation itself, communication channels, time, and a social system. The process of adopting new innovations has been studied for over many decades, and one of the most popular adoption models is described by Rogers in his book, Diffusion of Innovations (Sherry \& Gibson, 2002). Much research from a broad variety of disciplines has used the model as a framework. Dooley (1999) and Stuart (2000) mentioned several of these disciplines as communications, political science, public health, history, economics, technology, and education, and defined Rogers' theory as a widely used theoretical framework in the area of technology diffusion and adoption. Among the four main elements that influence the spread of a new idea, the most relevant to the ideas critical to this study is communication channels which are the second element in the diffusion process.

According to Rogers (2003), communication is "a process in which participants create and share information with one another in order to reach a mutual understanding" (p.5). Rogers states that "a source is an individual or an institution that originates a message. A channel is the means by which a message gets from the source to the receiver" (p.204). He states that diffusion is a specific kind of communication and includes these communication elements: an innovation, two individuals or other units of adoption, and a communication channel. Mass media and interpersonal communication are two communication channels. While mass media channels include a mass medium such as television, radio, or newspaper, interpersonal channels consist of a twoway communication between two or more individuals. On the other hand, "diffusion is a very social process that involves interpersonal communication relationships" (Rogers, 2003, p.19). Thus, interpersonal channels are more powerful to create or change strong attitudes held by an individual hence, the relevance of the theory to this study.

This study evaluated the communication strategies used by extension agents in disseminating the New Rice for Africa (NERICA) farming technology in Ofada, Owode Local Government Area of Ogun state, Nigeria from 2003 to 2018. The study therefore, was limited to rice farmers in Ofada and extension agents who work in that region. Population Figures of the farmers and extension workers under investigation according to the Farmers' Cooperative Societies Records in Ofada (2018) were twenty thousand two hundred and fifty nine $(20,259)$ and ninety-five (95) respectively. Communication strategies such as one to one, group training, handbills/posters, farm/house visits and radio broadcast programs/jingles utilized within the stated period were evaluated to determine their suitability and effectiveness level in conveying messages promoting NERICA technology and in motivating farmers towards adoption. The general objective of this study was to evaluate the effectiveness of communication strategies used by extension agents in disseminating the new rice for Africa (NERICA) technology information among rice farmers in Ofada, Ogun state, Nigeria. To actualize this, the study identified the communication strategies adopted in disseminating the NERICA technology, the effectiveness of the communication strategies in fostering understanding of the NERICA technology, the extent to which the communication strategy has increased the knowledge, interest and adoption of the NERICA technology as well as the level of rice production by farmers after adoption.

The study was guided by one hypothesis:

Ho1: Extension agents' communication strategies have no positive influence on knowledge of rice farmers about NERICA technology. 


\section{Methodology}

This study adopted the survey research design. It is considered appropriate for this kind of study because it enabled the researchers reach and examine the two different categories of people that were investigated: agricultural extension workers and rice farmers. A combination of structured questionnaire, and focus group discussion guide were used to elicit responses from extension agents and rice farmers.

The sampling technique that was adopted for the quantitative aspect of this study is the total enumeration sampling method due to the low number of extension workers that were examined. For the qualitative aspect of the study, which involved farmers, the purposive sampling method was adopted since all the farmers cannot participate in the focused group discussion. The criterion for inclusion for farmers in the locality was rice farming, while extension workers that were studied were those working in Owode LGA of Ogun state. Focus Group Discussions (FGD) with rice farmers were organized during their various Farmers' Cooperative Society meetings holding at various meeting points between Mondays and Saturdays, while the survey instrument used for extension workers was administered at their offices at the local government headquarters during working hours. The collected data was analyzed, using the simple linear regression analysis for the hypothesis which was done using the Statistical Products and Services Solution (SPSS) version 21.

\section{Data Analysis, Results and Discussion of Findings}

$\boldsymbol{R} \boldsymbol{q}$ 1: What are the communication strategies employed by extension workers in disseminating NERICA technology to rice farmers in Ofada, Ogun State?

Table 1: Communication Strategies Employed by Extension Workers

\begin{tabular}{|c|c|c|c|c|c|c|c|}
\hline $\mathbf{S} / \mathbf{N}$ & Items & $\begin{array}{l}\text { Strongly } \\
(\%)\end{array}$ & Agree & $\begin{array}{l}\text { Agree } \\
(\%)\end{array}$ & $\begin{array}{l}\text { Disagree } \\
(\%)\end{array}$ & $\begin{array}{l}\text { Strongly } \\
\text { Disagree }\end{array}$ & $\begin{array}{l}\text { Undecided } \\
(\%)\end{array}$ \\
\hline 1 & $\begin{array}{l}\text { One-on-One } \\
\text { communication }\end{array}$ & $21(22.8)$ & & $46(50.0)$ & $22(23.9)$ & $1(1.1)$ & $2(2.2)$ \\
\hline 2 & Group meetings & $58(63.0)$ & & $33(35.9)$ & $1(1.1)$ & - & - \\
\hline 3 & Handbills/posters & $35(38.0)$ & & $44(47.8)$ & $13(14.1)$ & - & - \\
\hline 4 & SMS & $57(62.0)$ & & $33(35.9)$ & $2(2.2)$ & - & - \\
\hline 5 & Radio broadcasts & $2(2.2)$ & & $58(63.0)$ & $32(34.8)$ & - & - \\
\hline 6 & Video demonstration & $28(30.4)$ & & $46(50.0)$ & $18(19.6)$ & - & - \\
\hline 7 & Manuals and notes & $57(62.0)$ & & $26(28.3)$ & $9(9.8)$ & - & - \\
\hline 8 & Cooperative gatherings & $60(65.2)$ & & $27(29.3)$ & $5(5.4)$ & - & - \\
\hline
\end{tabular}

$\boldsymbol{R q} 2$ : How effective were the various communication strategies in fostering understanding about NERICA technology among rice farmers in Ofada, Ogun State?

Table 2: Effectiveness of communication strategies used by extension agents

\begin{tabular}{llccccc}
\hline S/N & Items & $\begin{array}{c}\text { Highly } \\
\text { Effective } \\
(\mathbf{\%})\end{array}$ & $\begin{array}{c}\text { Effective } \\
(\mathbf{\%})\end{array}$ & $\begin{array}{c}\text { Fairly } \\
\text { Effective } \\
(\boldsymbol{\%})\end{array}$ & $\begin{array}{c}\text { Not } \\
\text { Effective } \\
(\%)\end{array}$ & $\begin{array}{c}\text { Not Effective at } \\
\text { all }(\%)\end{array}$ \\
\hline 1 & One-on-One communication & $61(66.3)$ & $31(33.7)$ & - & - & - \\
\hline 2 & Group meetings & $75(81.5)$ & $15(16.3)$ & $2(2.2)$ & - & - \\
\hline 3 & Handbills/posters & $40(43.5)$ & $30(32.6)$ & $22(23.9)$ & - & - \\
\hline 4 & SMS & $6(6.5)$ & $42(45.7)$ & $44(47.8)$ & - & - \\
\hline 5 & Radio broadcasts & $7(7.6)$ & $52(56.5)$ & $33(35.9)$ & - & - \\
\hline 6 & Video demonstration & $30(32.6)$ & $49(53.3)$ & $13(14.1)$ & - & - \\
\hline 7 & Manuals and notes & $13(14.1)$ & $37(40.20$ & $42(45.7)$ & - & - \\
\hline 8 & Cooperative gatherings & $73(79.3)$ & $15(16.3)$ & $4(4.3)$ & - & - \\
\hline
\end{tabular}

$\boldsymbol{R q} 3$ : To what extent did these communication strategies help in enhancing the knowledge of rice farmers about NERICA technology?

Table 3: Extent to which Communication Strategies enhanced the Knowledge of rice famers about NERICA

\begin{tabular}{llccccc}
\hline S/N & Items & $\begin{array}{c}\text { Very High } \\
(\mathbf{\%})\end{array}$ & $\begin{array}{c}\text { High } \\
(\mathbf{\%})\end{array}$ & $\begin{array}{r}\text { Low } \\
(\mathbf{\%})\end{array}$ & $\begin{array}{c}\text { Very } \\
\text { Low (\%) }\end{array}$ & $\begin{array}{c}\text { Not at } \\
\text { All (\%) }\end{array}$ \\
\hline 1 & One-on-One communication & $19(20.7)$ & $19(20.7)$ & $54(58.7)$ & - & - \\
\hline 2 & Group meetings & $47(51.1)$ & $39(42.4)$ & $6(6.5)$ & - & - \\
\hline 3 & Handbills/posters & $25(27.2)$ & $19(20.7)$ & $48(52.2)$ & - & - \\
\hline 4 & SMS & $11(12.0)$ & $22(23.90$ & $59(64.1)$ & - & - \\
\hline 5 & Radio broadcasts & $8(8.7)$ & $22(23.9)$ & $62(67.4)$ & - & - \\
\hline 6 & Video demonstration & $21(22.8)$ & $18(19.6)$ & $53(57.6)$ & - & - \\
\hline 7 & Manuals and notes & $6(6.5)$ & $25(27.2)$ & $61(66.3)$ & - & - \\
\hline 8 & Cooperative gatherings & $47(51.1)$ & $37(40.2)$ & $8(8.7)$ & - & - \\
\hline
\end{tabular}




\section{Focus Group Discussion}

Focus group discussions were conducted among five different groups, comprising eleven participants in each of the first four groups, while the fifth group is made up of twelve participants. Findings from the discussion were used to provide answer to research question four, five and six. It was moderated by the researchers.

Finding from our discussion with the farmers revealed that their first contact with NERICA was through extension agents who came to them during their cooperative gatherings and meetings to speak about the technology. It was during this period that information like the use of pesticides, control measures, and harvesting was exposed to them. It was also revealed that NERICA technology improved farmers' skills and knowledge about rice farming. There were also attestations to the fact that NERICA farming method is better than the traditional method of rice farming which they were used to because of its sophisticated and improved nature. The farmers affirmed the fact that NERICA technology if properly carried out significantly increase rice yield.

With reference to some of the challenges faced by farmers in the adoption of the technology, the following were identified: None availability of seedlings, none availability of equipment used for seed preservation, expensive nature of NERICA technology, complicated nature of NERICA technology, unfulfilled promises on the side of government. The farmers also unanimously preferred the one-to-one communication approach with the extension workers because it gives opportunity for a face-to-face contact and personalized interaction between them and the extension agents. These interactions enable answers and solutions which could be tailored towards individual farmer's needs. Based on the aforementioned the one-to-one communication strategy is considered to be the flagship of extension work because it gives opportunity for on-site appraisal of farm situations, questions and professional advice.

Overall, findings show that NERICA method offers more improved yield, both in terms of quantity and quality compared to other methods. However, government should assist by making available seedlings, seed preservation equipment, chemicals, reduction in the prices of fertilizers. There is also the need for closer interaction between farmers and extension workers in order to facilitate understanding of personal farm needs. Finally, there is need for a regular assessment of extension workers' activities by the government in other to regulate and ensure quality extension services to farmers.

\section{Test of Hypothesis}

Ho1: Extension agents' communication strategies have no positive influence on knowledge of rice farmers about NERICA technology.

Table 4: Regression Analysis Result on Communication Strategies and Knowledge of Rice Farmers

\begin{tabular}{|c|c|c|c|c|c|c|c|}
\hline & & \multicolumn{2}{|c|}{$\begin{array}{l}\text { Unstandardized } \\
\text { Coefficients }\end{array}$} & \multirow[b]{2}{*}{$\mathbf{R}^{2}$} & \multirow[b]{2}{*}{$F$} & \multirow[b]{2}{*}{ Sig. } & \multirow[b]{2}{*}{ Remark } \\
\hline \multicolumn{2}{|c|}{ Model } & B & Std. Error & & & & \\
\hline \multirow[t]{2}{*}{1} & (Constant) & 17.611 & 2.808 & & & 0.000 & Significant \\
\hline & Communication Strategies & .510 & .103 & 0.5 & 4.688 & & \\
\hline
\end{tabular}

The linear regression analysis of coefficient reveals that there is a positive relation between communication strategy employed by extension workers and knowledge of rice farmers about NERICA. This was validated in figures $\left(\mathbf{R}^{\mathbf{2}}=\mathbf{. 5 6 4} * *, \mathbf{F}_{(\mathbf{2}, \mathbf{9 5})}=\mathbf{2 4 . 6 8 8}, \mathbf{P}<\mathbf{. 0 0 0}\right)$. The result as shown in the bracket reveals the p-value as .000 which implies that the null hypothesis is rejected. Therefore, the conclusion of the hypothesis result is that there exists a positive influence between communication strategies of extension agents and its impact on the knowledge of rice farmers about NERICA technology in Ofada, Ogun State.

\section{Discussion of findings}

Evidence from the data revealed that the communication strategies employed by extension agents to reach rice farmers were one-on-one communication, group meetings, handbills/posters, SMS, radio broadcasts, video demonstration, manuals and notes, and cooperative gatherings. This finding is similar to that of Ashlock, Cartmell and Kelemen (2006) who reported that agricultural communication can take three modes; face-to-face training, training "products" such as manuals and videos, or information and communication technologies (ICTs), such as radio and short message System (SMS). Similarly, the outcome of the study aligns with that of Jamilah, Azril, Jegak, Asiah \& Azman (2010) which reported that extension workers go to meet with farmers in their homes, farms, markets gathering or during town hall or cooperative meetings and make them aware of the latest farming technologies and techniques. It is important, therefore, to note that employing these communication strategies can help extension agents to properly diffuse new innovations that would be more easily adopted by the users. Extension work has to do with the transfer of knowledge and the education of rural dwellers in adopting modern ways of carrying out specific activities, in relation to farming, health, or environments, it is imperative that change agents adopt simplified communication techniques such as one-to-one communication 
strategy that are direct and are capable of creating lasting impression in the minds of end users of a new innovation. Adoption of this kind of strategy can eliminate literacy barriers and delayed feedbacks.

The effectiveness of communication strategies employed by extension agents was examined and it was found that group meetings, cooperative gatherings, one-to-one communication and handbills/posters were highly effective as against the rest such as SMS, radio broadcasts, video demonstration, and manuals and notes which were effective and fairly effective respectively. This result resonates the findings of Jamilah, Azril, Jegak, Asiah \& Azman (2010) that extension workers go to meet with farmers in their homes, farms, markets gathering or during town hall or cooperative meetings to address them on various developmental issues associated with NERICA technology. Similarly, Quarry (2004) was of the view that most communication strategies are effective because of their information richness through the sharing of knowledge. It makes technical know-how accessible thereby leading to increased knowledge about the production, transformation, organization, pricing and marketing dimensions of agricultural products.

The result from the focused group discussion conducted by the researchers indicates that all the participants were knowledgeable about NERICA technology through extension agents who addressed them during various cooperative gatherings as well as personalized meetings. This has led to increase in knowledge and remarkable improvement in rice farming skills. To this end, there is attestation to the fact the NERICA method of farming is better and enhances rice yield. However, there are challenges with NERICA, these include none availability of seedlings, none availability of equipment used for seed preservation, expensive nature of NERICA technology, the seemingly complicated nature of NERICA technology, failed promises on the side of government, unavailability of equipment and inadequate support from the government in terms of finance, reduction in fertilizer prices, lack of market information, poor extension services and high cost of chemicals. Failed government promises as identified by farmers could be as a result of lack of continuity. Every successive government begins with a new project rather than continuing the previous one started by the past government administration.

The communication strategy that best stimulates rice farmers' interest as discovered in the study is one-toone communication, due to its advantage of having a face-to-face contact with extension workers. Farmers suggested that extension agents should improve on one-to-one communication strategy to reach more rice farmers because of the inadequacies of group and cooperative meetings. This means that effective communication between change agents and farmers as well as right choice of information channel is essential for the adoption of improved technology towards the achievement of higher productivity. There are indications that the use of NERICA technology brought about an increase in rice production compared to traditional methods. To this end, rice farmers appealed for more of government in the provision of seedlings, seed preservation equipment and regular evaluation of extension workers activities. The outcome of this study is in line with the finding of Bzugu, Mustapha and Zubairu (2010) who recommended that extension services of the state agricultural development should establish a closer relationship with rice farmers and that adequate provision of inputs (agricultural credits) should be provided at the right time.

\section{Conclusion}

In the light of the discoveries from the study, it is recommended that, extension workers should work closely with rice farmers on one-to-one basis, to understand their personal farm needs, rather than providing group support as they do most times. Government should also regularly evaluate the activities of the extension workers to ensure adequate delivery of proper support to rice farmers at both state and national level. Finally, government should support rice farmers through the provision of seedlings, seed preservation equipment, pesticides, herbicides and reduction in the price of fertilizer.

\section{References}

Adedeji T. O., Nosiru M. O., Akinsulu A. A.,Ewebiyi I. O., Abiona B. G. \& Jimoh T. S. (2013). Adoption of New Rice for Africa (NERICA) technology in Ogun State, Nigeria.Journal of Development and Agricultural Economics. 5(9), 365-371, DOI 10.5897/JDAE12.165 Available at http://www.academicjournals.org/JDAE. Assessed 10/09/2016

Adesina, A. (2013). Rice Consumption and Importation in Nigeria, No Solution in Sight. Vanguard Newspaper, December 30, 2013: http://www.vanguardngr.com/2013/12/

Adefila, J.J. (2008). Research Methodology in behavioural science (First Edition). Kaduna: Apain Publishers.

Adegbola, P, Arouna A., Diagne A., \&Adekanmbi, S. A. (2005). Determinants socio-economic ettauxd'adoption et d'adoption des nouvelles varieties de riz NERICA au Centre du Benin. Papier a soumettre pour publication.

Africa Rice Centre (WARDA)/FAO/SAA (2008). NERICA: the New Rice for Africa - a Compendium. Somado EA, Guei RG, Keya SO (eds.). Cotonou, Benin: Africa Rice Center (WARDA); Rome, Italy: FAO; Tokyo, Japan: Sasakawa Africa Association. 
Agbamu, J.U. (1993). Analysis of farmers characteristics associated with adoption of soil management innovations in Ikorodu L.G. A. of Lagos State, Nigeria. Journal of Rural Extension Development.1(2): 51 67.

Agunga, R. \& Manda, Z. L., (2014). Communication for Strengthening Agricultural Extension and Rural Development in Malawi. Journal of Development and Communication Studies 3.(1); 1-16. Available at http://www.devcomsjournalmw.org. Accessed 10/09/2016

Ajzen, I., \& Fishbein, M. (1980).Understanding attitudes and predicting social behavior. Englewood Cliffs, NJ: Prentice-Hall.

Aker, J. C. 2010. Dial A for Agriculture: Using Information and Communication Technologies for Agricultural Extension in Developing Countries. Tuft University, Economics Department and Fletcher School, Medford MA02155.

Akpokodje, G., F. Lancon\& E. Olaf. 2002. Nigeria's rice policy and development: A review. Final draft. West African Rice Development Association, Abidjan, Côte d'Ivoire.

Ali, A., Mohammad A., \& Ebraheem A., (2012).Effectiveness of Agricultural Extension Activities. American Journal of Agricultural and Biological Sciences 7 (2): 194-200.

Anaeto, S. G., Onabajo, O. S., \& Osifeso J. B. (2008).Models and Theories of Mass Communication. Lagos: African Renaissance Book Publication.

Asika, N. (2005). Research Methodology in the Behavioural Science. Lagos: Longman Nigeria Ltd.

Ashlock, M., Cartmell, D., \& Kelemen, D. (2006). The Cow That Stole Christmas: Framing the First U.S. Mad Cow Crisis. Journal of Applied Communications, 90(2) 29-46

Audebert, A., Dingkuhn, M., Jones, M.P. \& Johnson. E. (1998), "Physiological Mechanisms for Vegetable Vigour of Interspecific Upland Rice - Implication for Weed Competitiveness" Japanese Journal of Crop Science, 67(2) 358-359.

Awoniyi, S. A., Aderanti, R. A., \& Tayo, A. S. (2011).Introduction to Research Methods. Ibadan: Ababa Press Ltd.

Baran, S. J. \& Davis, D. K. (2003). Mass Communication Theory, Foundations, Ferment, and Future, Belmont (USA): Thomas-Wardworth.

Barker, K. (2004) Diffusion of innovations: A world tour. Journal of Communication, 9:131-137

Bellù, L. G. (2011).Development and Development Paradigms: A (Reasoned) Review of Prevailing Visions. Food and Agriculture Organization (FAO) of The United Nations. Available at www.fao.org/easypol assessed 04/04/2016.

Blumberg, R.L. (1987). Organizations in Contemporary Society. Prentice Hall Inc. New Jersey. pp 99-114

Bordenave, J. (1976). "Communication and Agricultural Innovations in Latin America" Communication and Development: Critical Perspectives. Rogers, Everett (ed). Beverly Hills, California. Sage Publications. Pp. 43-62.

Boone, K., Meisenbach, T., \& Tucker, M. (2000).Agricultural communications: Changes and challenges, Iowa State University Press.

Bourdillon M, Hebinck P, Hoddinott J, Kinsey B, Marondo J, Mudege N, \&Owens T (2002). Assessing the Impact of HYV Maize in Resettlement Areas of Zimbabwe. Discussion paper 161, Washington, D.C: Int. Food Policy Res. Inst.

Bryman, A. \& Bell, E. (2011).Business Research Methods.3 ${ }^{\text {rd }}$ Edition. New York: Oxford University Press Inc.

Brunner, E. \& Hsin Pao Yang, E. (1949) Rural America and the Extension Service Columbia University Press.

Bzugu, P. M., Mustapha, S. B. \& Zubairu, E.A, (2010).Adoption of NERICA 1 rice variety among farmers in Jalingo Local Government area of Taraba State, Nigeria. Journal of Environment Issues and Agriculture in Developing Countires, Volume 2 Number $2 \& 3$.

Chauhan, J. (2007). Communication in Agriculture. New Delhi: Concept Publishing Company.

Chukwuemeka, E. \& Nzewi, H. N. (2011).An empirical study of World Bank Agricultural Development Programme in Nigeria. American Journal of Social and Management Sciences. Science Huß.Available at http://www.scihub.org/AJSMS. Accessed 08/04/2016.

Davis, F. D. (1986). A technology acceptance model for empirically testing new end-user information systems: Theory and results. Doctoral Dissertation. Cambridge, MA: MIT Sloan School of Management.

Davis, F. D. (1989), Perceived Usefulness, Perceived Ease of Use, and User Acceptance of Information Technology, MIS Quarterly, 13, (3); 319-340.

Davis, F. D., Bagozzi, R. P., \& Warshaw, P. R. (1989). User acceptance of computer technology: A comparison of two theoretical models. Management Science, 35(8), 982-1003.

Davidson, J. E. (2005). Evaluation Methodology Basics: The nuts and bolts of sound evaluation. Thusand Oaks, CA:Sage.

De Janvry, A. \& Sadoulet, E. (1992). Structural Adjustment under Transaction Costs. Paper presented at the 29th Meeting of the European Association of Agricultural Economists on Food and Agriculture Under Structural 
Adjustment, University of Hohenheim, Stuttgart, 1992 (Frankfurt am Main, Germany: P. Lang, 1994).

Diagne A (2006a). The diffusion and adoption of NERICA rice varieties in Côte d'Ivoire'. Dev. Econ. 44(2):208231.

Diagne A, Sogbossi M. J., Sékou D, Diallo A. S., \&Bacar, B. A. (2007). Evaluation de la diffusion et de l'adoption des variétés de riz NERICA enGuinée. Miméo ADRAO, 2007. Paper presented at the AAAE 2nd Conference, 19-22 August 2007, Accra.

Dingkuhn, M., Jones, M.P., Johnson, D. E. and Sow, Abdoulaye (1998), Growth and Yield Potential of Oryza sativa and O. glabarrima Upland Rice and their Interspecif Progenies Field Crops Research 57, 57-69.

Doerfert, D. L. (Ed.) (2011). National research agenda: American Association for Agricultural Education's research priority areas for 2011-2015. Lubbock, TX: Texas Tech University, Department of Agricultural Education and Communications.

Dooley, K.E. (1999). Towards a holistic model for the diffusion of educational technologies: An integrative review of educational innovation studies. Educational Technology \& Society 2(4), 35-45.

Erie, A. P. (2009). A conceptual framework for the privatization and commercialization of agricultural extension services: A case study of Edo State, Nigeria. Rudel printers and publishers, Edo State, Nigeria. PP 1, 4, 25

Ephraim, A. O.\& Gloria O. O. (2013).Information and Communication Technology and Enhancement of Agricultural Extension Services in the New Millennium. Journal of Educational and Social Research Vol. 3 (4); $155-159$

FAO (2001). Rice Statistics. Website: http://www.riceweb.org.Accessed 10/09/2016.

Fraser, C. \& Restrepo - Estrada, S. (1998) Communication for Development: Human change for survival; London

Jamilah, O., M. S. H. Azril, U. Jegak, M. Asiah\& A.N. Azman(2010). Can quality of work life affect work performance among government agriculture extension officers? A case from Malaysia. Journal of Social Science, 6: 64-73.

Ogidi, A. E. (2015). Importance of Communication in Sustaining Nigeria Agriculture.International Journal of Information and Technology, 1, (1); 42-48. International Academic Journal for Global Research (iajgr) Publishing (USA).

Ogundele, O. O. \& Okoruwa, V. O. (2006).Technical efficiency differentials in rice production technologies in Nigeria. AERC Research Paper 154 African Economic Research Consortium, Nairobi: The Regal Press Ltd.

Ogunremi, J. B. (2013). Assessment of Extension Agents' Use of Communication Methods and its Impact on Aquaculture Linkage Activities in Lagos State, Nigeria.Journal of Agriculture and Social Research, 13(1). 15

Ojehomon, V.E.T., Ayinde, O. E., Adewumi, M. O. \&Omotesho, O.A. (2013). Determinant of Technical Efficiency of New Rice for Africa (NERICA) Production: A Gender Approach. Ethiopian Journal of Environmental Studies and Management 6 (5)

Project Co-ordinating Unit (PCU) (2002): .Crop Area Yield Survey (CAY).Federal Ministry of Agriculture and Rural Development, Abuja.

Rogers, E.M. (2003). Diffusion of Innovations (5th ed.). New York: Free Press.

Sherry, L. (1997). The boulder valley internet project: Lessons learned. THE (Technological Horizons in Education) Journal, 25(2), 68-73.

Sinkaiye, T. (2005). Agricultural Extension Participatory Methodologies and Approaches in Agricultural Extension in Nigeria. AESON, Ilorin.

Stuart, W.D. (2000). Influence of sources of communication, user characteristics and innovation characteristics on adoption of a communication technology (Doctoral dissertation, The University of Kansas, 2000).ProQuest Digital Dissertations.(UMI No.AAT 9998115).

Tchale, H. (2009).The efficiency of smallholder agriculture in Malawi. AFJARE, Vol. 3 (2):101-121

Tiamiyu S. A. (2008). Efficiency and Technology Use among Growers of NERICA Rice Varieties in the Savanna Zone of Nigeria.Unpublished Ph.D Thesis, University of Ibadan.

West Africa Rice Development Association (WARDA) and Nigerian Institute of Social and Economic Research (NISER) (2001): Report of the Stakeholders Workshop. November 8-9, 2001. Ibadan, Nigeria.

William, S.K.T., Fenley, J.M \& Williams, C. E. (1984).A Manual for Agricultural Extension Workers in Nigeria.pp. 77-95. 